\title{
Reaksi Pasar terhadap Peristiwa Politik 2019 di Indonesia
}

\author{
Ni Luh Dea Kemuning ${ }^{1}$ \\ Fakultas Ekonomi dan Bisnis \\ Universitas Pendidikan Nasional, \\ Indonesia
}

\author{
Ida Bagus Teddy Prianthara ${ }^{2}$ \\ Fakultas Ekonomi dan Bisnis \\ Universitas Pendidikan Nasional, \\ Indonesia
}

\section{Made Andika Pradnyana Wistawan ${ }^{3}$ \\ Fakultas Ekonomi dan Bisnis Universitas Udayana, Indonesia}

\begin{abstract}
Surel : deakemuning@gmail.com
ABSTRAK

Penelitian ini menguji adanya kandungan informasi dalam peristiwa politik di tahun 2019, yaitu penetapan presiden dan wakil presiden dan pengumuman Kabinet Indonesia Maju. Reaksi pasar diukur dengan abnormal return, security return variability, dan trading volume activity. Periode pengamatan dalam penelitian ini adalah lima hari sebelum dan sesudah peristiwa, dengan jumlah sampel perusahaan yang berafiliasi dengan pemenang pemilu sejumlah 20 perusahaan dan 25 perusahaan pada peristiwa pengumuman Kabinet Indonesia Maju. Hasil pengujian hipotesis menunjukkan bahwa terdapat perbedaan rata-rata abnormal return pada peristiwa penetapan presiden dan wakil presiden terpilih, namun tidak ditemukan adanya perbedaan security return variability, dan trading volume activity. Selanjutnya, pengujian hipotesis menunjukkan bahwa terdapat perbedaan rata-rata trading volume activity yang signifikan sebelum dan sesudah peristiwa pengumuman Kabinet Indonesia Maju, namun tidak ditemukan adanya perbedaan abnormal return dan security return variability.

Kata Kunci: Efisiensi Pasar; Event Study; Abnormal Return; Security Return Variability; Trading Volume Activity.
\end{abstract}

\section{Market Reaction to 2019 Political Events in Indonesia}

\section{ABSTRACT}

This study examines the information content in political events in 2019, namely the appointment of the president and vice president and the announcement of the Kabinet Indonesia Maju. Market reaction is measured by abnormal returns, security return variability, and trading volume activity. The observation period in this study was five days before and after the event, with a sample of 20 companies affiliated with the winner of the election and 25 companies at the announcement of the Indonesian Maju Cabinet. The results of hypothesis testing indicate that there is a difference in the average abnormal return in the event of the appointment of the elected president and vice president, but there is no difference in security return variability and trading volume activity. Furthermore, hypothesis testing shows that there is a significant difference in average trading volume activity before and after the announcement of the Kabinet Indonesia Maju, but there is no difference in abnormal return and security return variability.

Keywords: $\quad$ Market Efficiency; Event Studies; Abnormal Returns; Security Return Variability; Trading Volume Activity.

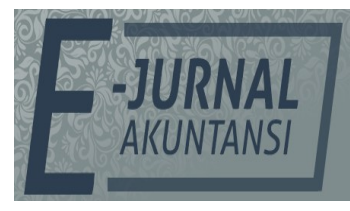

e-ISSN 2302-8556

Vol. 31 No. 7

Denpasar, Juli 2021

Hal. 1746-1759

DOI:

10.24843/EJA.2021.v31.i07.p11

PENGUTIPAN:

Kemuning, N.L.D.,

Prianthara, I.B.T., \&

Wistawan, I M.A.P. (2021).

Reaksi Pasar terhadap

Peristiwa Politik 2019 di Indonesia. E-Jurnal Akuntansi, 31(7), 1746-1759

RIWAYAT ARTIKEL:

Artikel Masuk: 11 Mei 2021

Artikel Diterima: 16 Juli 2021

Artikel dapat diakses : https://ojs.unud.ac.id/index.php/Akuntansi/index 


\section{PENDAHULUAN}

Pasar efisien adalah kondisi dimana pasar bereaksi dengan cepat dan akurat untuk mencapai harga keseimbangan baru, yang sepenuhnya mencerminkan informasi yang tersedia. Efisiensi pasar ini disebut sebagai efisiensi pasar secara informasi (informationally efficient market) (Ghofar \& Aunilah, 2016). (Fama \& French, 2005) dalam penelitiannya mengklasifikasikan pasar efisien dalam tiga bentuk yaitu efisiensi pasar bentuk lemah (weak form), efisiensi pasar bentuk setengah kuat (semi-strong form), dan efisiensi pasar bentuk kuat (strong form). Pasar efisien bentuk setengah kuat mengasumsikan bahwa harga pasar tidak hanya mencerminkan infomasi di masa lalu, tetapi juga mencerminkan seluruh informasi yang dipublikasikan saat ini. Informasi yang dipublikasikan dapat berupa informasi ekonomi dan non-ekonomi. Informasi ekonomi dapat berupa perubahan manajemen, penerbitan saham baru, merger, pengungkapan laporan keuangan, akuisisi atau kebangkrutan. Peristiwa non-ekonomi biasanya terjadi karena faktor politik atau geostrategis (Obradovic \& Tomic, 2017) dan (Sajid Nazir, Younus, Kaleem, \& Anwar, 2014). Peristiwa politik maupun tindakan pemerintah memiliki potensi untuk mempengaruhi fluktuasi pasar modal, yang nantinya akan menentukan kesejahteraan keuangan masyarakat di suatu negara (Wisniewski, 2016). Pelaku ekonomi di suatu negara berpendapat bahwa peristiwa politik tidak bisa diabaikan begitu saja karena dapat menimbulkan risiko positif ataupun negatif terhadap kelangsungan ekonomi negara tersebut (Nurlita \& Naomi, 2019). Bechtel (2009) mengungkapkan bahwa meskipun tidak berhubungan secara langsung terhadap pasar modal, kestabilan situasi politik di suatu negara akan mendorong pertumbuhan investasi modal.

Pemilihan umum nasional, dalam sistem negara demokratis, adalah peristiwa politik utama yang memiliki implikasi penting bagi masa depan kebijakan ekonomi negara. Sebagai konsekuensi, peristiwa ini menimbulkan ketidakpastian besar bagi investor domestik dan asing (Mei \& Guo, 2004). Pengaruh pemilu terhadap kinerja pasar saham dapat disebabkan oleh ekspektasi investor terhadap perubahan kebijakan pemerintah yang dilakukan oleh partai atau orang baru yang terpilih. Kebijakan ini akan mempengaruhi berbagai aspek, seperti contohnya tarif pajak yang berhubungan dengan kinerja perusahaan. Investor akan berinvestasi di pasar saham jika merasa optimis mengenai masa depan kondisi perekonomian. Sebaliknya, saat investor merasa tidak aman dengan masa depan perekonomian, mereka akan cenderung menarik diri dari pasar. Investor dan masyarakat umum, pada masa pemilu, akan terpengaruh oleh kampanye pemilu dan janji-janji dari calon, sehingga hal ini akan mempengaruhi keputusan investasi dan menyebabkan perubahan harga di pasar saham (Chavali, Alam, \& Rosario, 2020) dan (Jiun, 2018).

Beberapa penelitian event study telah dilakukan untuk menganalisis adanya suatu reaksi dari pasar modal terhadap peristiwa-peristiwa politik yang terjadi. Primastono (2006) meneliti reaksi pasar terhadap peristiwa pengumuman Kabinet Gotong Royong dan Kabinet Indonesia Bersatu menemukan bahwa tidak terdapatnya perbedaan rata-rata abnormal return dan trading volume activity sebelum dan sesudah peristiwa, yang menunjukkan bahwa meskipun peristiwa ini mengandung suatu informasi, namun tidak mampu menciptakan gejolak atas reaksi para investor. Penelitian Zaqi (2006) atas reaksi pasar terhadap peristiwa 
ekonomi dan sosial politik, yaitu Pemilu Presiden 1999 dan Reshuffle Kabinet di tahun 2000 menunjukkan bahwa perbedaan rata-rata security return variability sebelum dan sesudah peristiwa yang signifikan hanya terdapat pada peristiwa sosio-politik. Aditha \& Adiputra (2020) menemukan hasil yang sama dengan Primastono; bahwa tidak terdapat perbedaan rata-rata abnormal return dan trading volume activity sebelum dan sesudah pengumuman Kabinet Kerja Jokowi-JK. Penelitian yang dilakukan Gupta et al., (2017) tentang reaksi pasar modal India terhadap pemilu umum India 2014 menunjukkan bahwa pasar bereaksi positif terhadap kemungkinan perubahan pemerintahan setelah pemilihan pemerintahan yang baru. Yeh et al., (2013) juga menemukan hasil yang serupa; bahwa terdapat perubahan abnormal return yang signifikan saat peristiwa pemilu Lok Sabha di India. Nida et al., (2020) dalam penelitiannya menemukan bahwa peristiwa politik, dalam hal ini pengunduran diri mantan Presiden Pakistan Pervez Musharaf, memengaruhi harga saham dimana trading volume dan pengembalian saham berfluktuasi secara positif sebelum dan sesudah peristiwa.

Setiap investor memiliki reaksi berbeda terhadap good news maupun bad news. Saat investor melihat suatu informasi atau peristiwa sebagai bad news, volatilitas harga saham menjadi lebih tinggi dibandingkan dengan good news (Chavali et al., 2020) dan (Suleman, 2012). Keyakinan investor bahwa partai lawan akan menang dalam pemilu membuat mereka menduga akan ada perubahan kebijakan yang radikal dalam lingkup ekonomi makro. Ekspektasi terhadap perubahan kebijakan ini meningkatkan volatilitas pasar saham (Mnasri \& Essaddam, 2021) dan (Pastor \& Veronesi, 2012). Peristiwa yang akan diuji kandungan informasinya dalam penelitian ini adalah penetapan presiden dan wakil presiden terpilih 2019-2024 tanggal 30 Juni 2019 oleh Komisi Pemilihan Umum (KPU) dan peristiwa pelantikan Kabinet Indonesia Maju tanggal 23 Oktober 2019. Penetapan presiden dan wakil presiden terpilih ini dilangsungkan 3 hari setelah Mahkamah Konstitusi mengumumkan keputusan untuk menolak permohonan pasangan calon presiden Prabowo Subianto-Sandiaga Uno terkait gugatan hasil Pilpres 2019, yaitu pada tanggal 30 Juni 2019. IHSG mengalami kenaikan sebesar 0,33 persen pada hari Senin, 1 Juli 2019, sehari setelah penetapan, dibandingkan penutupan perdagangan di hari Jumat, 28 Juni 2019 sebelumnya. Beberapa hari sebelumnya, IHSG bergerak fluktuatif, yang diduga dikarenakan investor masih wait and see akan kepastian hasil keputusan Mahkamah Konstitusi atas gugatan hasil Pilpres 2019 kepada Bawaslu, namun sehari setelah penetapan, IHSG mengalami kenaikan akibat respons positif pasar terhadap kepastian terpilihnya presiden dan wakil presiden ini. Peristiwa pengumuman Kabinet Indonesia Maju dilaksanakan tanggal 23 Oktober 2019, 3 hari setelah pelantikan presiden dan wakil presiden Indonesia. Pengumuman Kabinet Indonesia Maju merupakan peristiwa yang dinanti para investor, karena ikut menentukan masa depan Indonesia ke depannya, terutama dalam bidang ekonomi. Sri Mulyani kembali dilantik sebagai Menteri Keuangan yang kemudian menjadi sebuah sentimen positif dan ditandai dengan masuknya investor asing kembali ke pasar saham domestik setelah keluar selama empat hari berturutturut. Erick Thohir merupakan sosok dari luar lingkup politik yang dianggap membawa angin segar di kabinet dengan latar belakang seorang pebisnis yang juga merupakan Ketua Tim Pemenangan Jokowi-Ma'ruf pada saat kampanye. Hal 
ini terefleksi pada 10 saham BUMN yang mengalami kenaikan sehari setelah pelantikan. Di hari yang sama, perdagangan ditutup dengan kenaikan sebesar 0,52 persen. Keesokan harinya di tanggal 24 Oktober 2019, IHSG kembali mengalami kenaikan sebesar 1,31 persen. Adapun di tanggal 25 Oktober 2019, setelah mengalami kenaikan selama sepekan, IHSG justru mengalami penurunan sebesar 1,38 persen. Fluktuasi pasar selama periode peristiwa tersebut terjadi menjadi suatu dasar untuk melakukan pengujian untuk melihat apakah peristiwa ini memiliki kandungan informasi yang dapat menyebabkan reaksi di pasar saham.
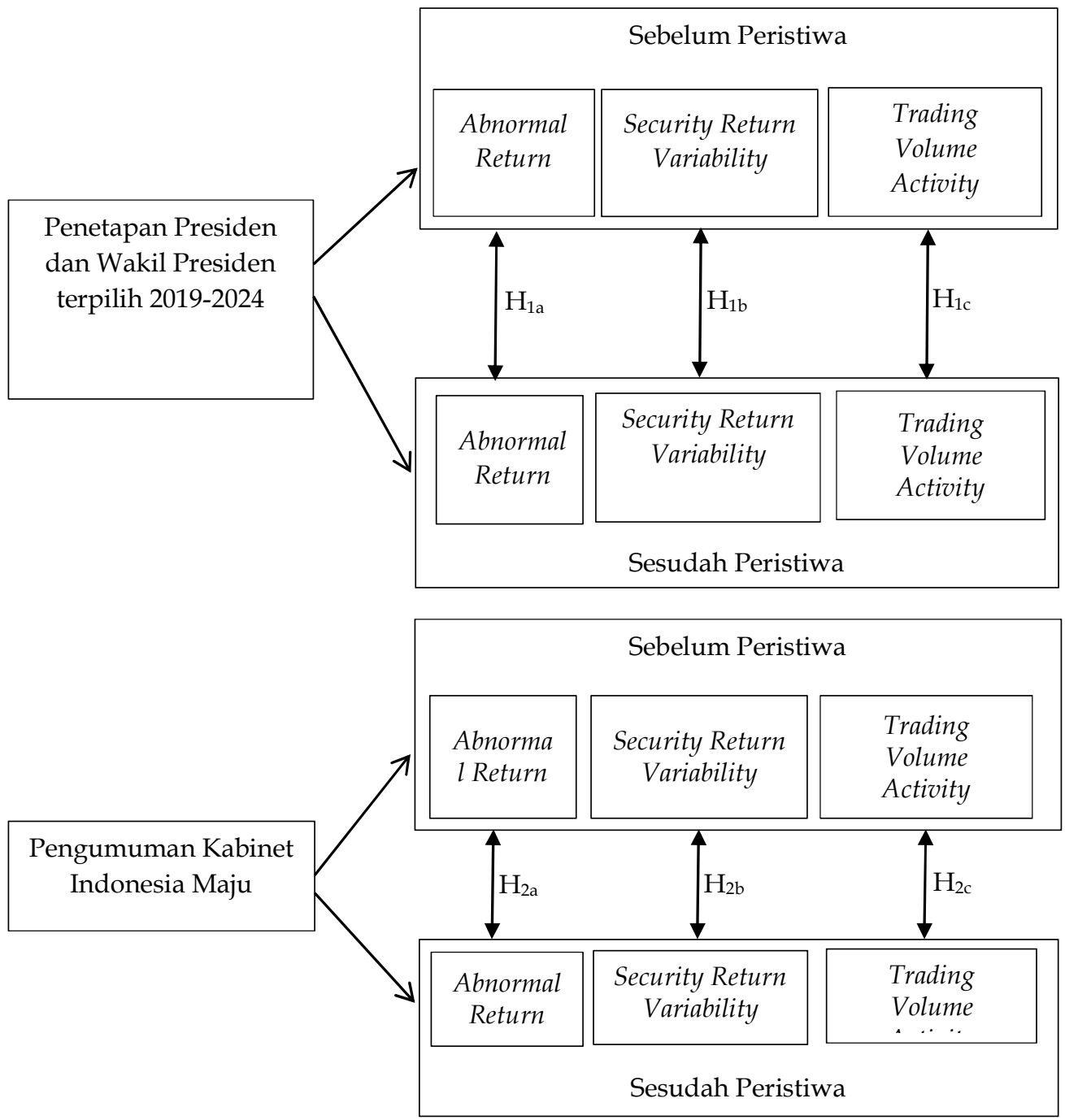

Gambar 1. Model Penelitian

Sumber: Data Penelitian, 2021

Peristiwa penetapan Presiden dan Wakil Presiden merupakan salah satu peristiwa yang dapat memengaruhi stabilitas politik, yang selanjutnya juga akan memengaruhi kestabilan ekonomi negara. Pertumbuhan ekonomi suatu negara dapat dilihat melalui kondisi pasar sahamnya (Irshad, 2017). Secara tidak langsung peristiwa pemilihan presiden akan memengaruhi aktivitas di pasar saham. Adanya informasi dari peristiwa pemilihan presiden ini akan 
memunculkan reaksi dari pasar saham, dan memicu pengambilan keputusan investasi (Fidiana, 2020). Peristiwa penetapan Presiden ini normalnya akan dilihat sebagai suatu good news, melihat penetapan ini resmi oleh KPU yang dilakukan setelah gugatan sengketa oleh tim lawan ditolak oleh Mahkamah Konstitusi, dan bukan merupakan hasil quick count semata. Selain itu, mengingat pemenangnya adalah incumbent yang diharapkan akan melanjutkan program infrastruktur dan keberlanjutan pertumbuhan ekonomi dan investasi, diharapkan pelaku investor akan merespon peristiwa ini sebagai good news dan menimbulkan reaksi pasar.

$\mathrm{H}_{1 \mathrm{a}}$ : Terdapat perbedaan signifikan rata-rata abnormal return sebelum dan sesudah peristiwa penetapan Presiden dan Wakil Presiden Terpilih 20192024 pada perusahaan afiliasi pemenang pemilu presiden 2019.

$\mathrm{H}_{1 \mathrm{~b}}$ : Terdapat perbedaan signifikan rata-rata security return variability sebelum dan sesudah peristiwa penetapan presiden dan wakil presiden terpilih 20192024 pada perusahaan- perusahaan koalisi pemenang pemilu.

$\mathrm{H}_{1 \mathrm{c}}$ : Terdapat perbedaan signifikan rata-rata trading volume activity sebelum dan sesudah peristiwa penetapan presiden dan wakil presiden terpilih 2019-2024 pada perusahaan-perusahaan koalisi pemenang pemilu.

Peristiwa seperti pengumuman kabinet menteri memiliki potensi kandungan informasi untuk mempengaruhi harga saham di bursa efek karena peristiwa politik berkaitan sangat erat dengan kestabilan perekonomian negara (Wisniewski, 2016). Perubahan yang terjadi pada lembaga eksekutif ataupun lembaga legislatif dapat mempengaruhi kondisi ekonomi suatu negara, karena kondisi ekonomi seringkali disebabkan oleh kebijakan-kebijakan yang di tentukan oleh lembaga eksekutif maupun lembaga legislatif. Variabilitas tingkat keuntungan yang meningkat pada saat pengumuman peristiwa dianggap sebagai bukti bahwa terdapat kandungan informasi yang mampu mengubah keyakinan investor dan harga-harga saham (McNichols \& Manegold, 1983). Dalam kaitannya dengan pengumuman kabinet, diharapkan bahwa adanya perbedaan variabilitas tingkat keuntungan sebelum dan sesudah peristiwa menandakan bahwa adanya kandungan informasi yang mampu memicu reaksi pasar saham dan keputusan para investor. Aktivitas volume perdagangan merujuk kepada jumlah pertukaran saham yang terjadi akibat transaksi jual dan beli di pasar saham. Volume perdagangan mengalami kenaikan saat investor dapat menginterpretasi sebuah informasi secara identik atau saat mereka memiliki perbedaan ekspektasi terhadap sebuah informasi (Karpoff, 1986). Dalam kaitannya dengan peristiwa pemilihan presiden dan pengumuman kabinet, diharapkan adanya perbedaan trading volume activity sebelum dan sesudah peristiwa. Berdasarkan penjabaran di kajian pustaka dan hubungan antar variabel, hipotesis yang diajukan dalam penelitian adalah sebagai berikut.

$\mathrm{H}_{2 \mathrm{a}}$ : Terdapat perbedaan signifikan rata-rata abnormal return sebelum dan sesudah peristiwa pengumuman Kabinet Indonesia Maju pada perusahaanperusahaan afiliasi pemenang pemilu presiden 2019.

$\mathrm{H}_{2 \mathrm{a}}$ : Terdapat perbedaan signifikan rata-rata security return variability sebelum dan sesudah peristiwa pengumuman Kabinet Indonesia Maju pada perusahaan-perusahaan koalisi pemenang pemilu. 
$\mathrm{H}_{2 \mathrm{a}}$ : Terdapat perbedaan signifikan rata-rata trading volume activity sebelum dan sesudah peristiwa pengumuman Kabinet Indonesia Maju pada perusahaan-perusahaan koalisi pemenang pemilu.

\section{METODE PENELITIAN}

Populasi dalam penelitian ini adalah perusahaan-perusahaan yang terdaftar di Bursa Efek Indonesia, yang pengelola atau pemiliknya berafiliasi dengan pemenang Pemilu 2019 dan tergabung dalam tim koalisi pemenangan JokowiMa'ruf, aktif diperdagangkan selama periode penelitian dan tidak melakukan corporate action dalam rentang periode penelitian. Periode penelitian untuk peristiwa penetapan presiden dan wakil presiden terpilih 2019-2024 pada tanggal 30 Juni 2019, dan untuk pengumuman Kabinet Indonesia Maju adalah pada tanggal 23 Oktober 2019. Harga saham perusahaan yang memiliki afiliasi akan meningkat saat hasil pemilu difinalisasi, jika mereka memiliki hubungan politis dengan partai yang menang (Shen \& Lin, 2015).

Informasi makro ataupun aksi individual korporasi perusahaan dicerminkan dalam pergerakan harga saham, volatilitas aktivitas dan keuntungan/kerugian yang diperoleh investor. Ketiga indikator ini menjadi alat ukur yang sering digunakan dalam pengukuran reaksi pasar atas informasi yang masuk ke pasar. Variabel penelitian yang digunakan dalam penelitian ini adalah Abnormal Return, Security Return Variability dan Trading Volume Activity. Masingmasing variabel penelitian dilakukan pengamatan sebelum dan sesudah peristiwa. Abnormal return merupakan kelebihan dari return yang sesungguhnya terjadi terhadap return normal. Return normal merupakan return ekspektasian, atau return yang diharapkan oleh investor. Security return variability atau variabilitas tingkat keuntungan adalah pendekatan yang digunakan untuk melihat apakah suatu informasi mengakibatkan perubahan pada distribusi return saham pada waktu pengumuman. Trading volume activity merupakan suatu instrumen yang dapat digunakan untuk melihat reaksi pasar modal terhadap informasi melalui parameter pergerakan aktivitas volume perdagangan di pasar. Trading volume activity (TVA) merupakan variasi dari event study. Perhitungan TVA dilakukan dengan membandingkan jumlah saham perusahaan yang diperdagangkan dalam suatu periode tertentu dengan keseluruhan jumlah saham beredar perusahaan tersebut pada kurun waktu yang sama (Setiawan \& Maret, 2008). Persamaan untuk mengukur TVA adalah sebagai berikut.

$\mathrm{TVA}_{\mathrm{i}, \mathrm{t}}=\frac{\Sigma \text { Saham i diperdagangkan waktu } \mathrm{t}}{\Sigma \text { Saham i beredar waktu } \mathrm{t}}$

Analisis penelitian menggunakan metode event study. Event study mengharuskan penggunaan event window selama 11 hari, yang terdiri dari t-5 (preevent, lima hari sebelum peristiwa), t0 (event day, hari terjadinya peristiwa), dan t+5 (post event, lima hari sesudah peristiwa. Rentang waktu selama 11 hari ditentukan untuk menghindari confounding effect yang dapat terjadi jika event window terlalu panjang (Flore et al., 2017). Setelah data terkumpul maka dilakukan uji normalitas data terlebih dahulu untuk mengetahui apakah data berdistribusi normal. Pengujian normalitas menggunakan Kolmogorov Smirnov Test. Jika data berdistribusi normal, pengujian hipotesis dilanjutkan dengan menggunakan uji parametrik Paired Sample t-test, sedangkan jika data berdistribusi tidak normal, 
dapat digunakan uji non parametrik, yaitu Wilcoxon Signed Rank Test (Jiun, 2018).

\section{HASIL DAN PEMBAHASAN}

Jumlah perusahaan yang terdaftar di Bursa Efek Indonesia (BEI) yang berafiliasi dengan pemenang pemilu selama periode pengamatan 10 hari adalah sejumlah 25 perusahaan. Dalam periode pengamatan di peristiwa penetapan presiden dan wakil presiden terpilih 2019-2024, terdapat 20 perusahaan yang memenuhi kriteria sampling, sedangkan untuk peristiwa pengumuman Kabinet Kerja 2019-2024, terdapat 25 perusahaan yang memenuhi kriteria sampling. Perbedaan jumlah perusahaan di kedua peristiwa tersebut disebabkan karena terdapat 5 perusahaan afiliasi membagikan deviden pada periode penetapan presiden dan wakil presiden 2019-2024. Perusahaan yang membagikan deviden dikeluarkan karena memiliki potensi noise reaction dalam reaksi pasar (Zaqi, 2006). Pengujian dilakukan dengam mencari rata-rata setiap variabel lima hari sebelum peristiwa, dan lima hari sesudah peristiwa.

Tabel 1. Statistik Deskriptif Variabel Penelitian pada Peristiwa Penetapan Presiden dan Wakil Presiden Terpilih 2019-2024 oleh KPU

\begin{tabular}{cccccc}
\hline Variabel & Periode & Minimum & Maximum & Mean & Std Deviation \\
\hline \multirow{2}{*}{ AR } & Sebelum & $-0,004$ & 0,062 & 0,006 & 0,015 \\
& Sesudah & $-0,028$ & 0,010 & $-0,005$ & 0,010 \\
SRV & Sebelum & 0,146 & 2,185 & 0,868 & 0,618 \\
& Sesudah & 0,069 & 2,954 & 0,996 & 0,759 \\
\multirow{2}{*}{ TVA } & Sebelum & 0,000 & 0,100 & 0,006 & 0,022 \\
& Sesudah & 0,000 & 0,020 & 0,002 & 0,004 \\
\hline
\end{tabular}

Sumber: Data Penelitian, 2021

Analisis statistik deskriptif untuk rata-rata AR sebelum peristiwa penetapan presiden dan wakil presiden terpilih 2019-2024 menunjukkan angka minimum sebesar -0,004 dan maksimum sebesar 0,062, dengan mean sebesar 0,006 dan standar deviasi sebesar 0,014. Sementara untuk rata-rata AR sesudah peristiwa, nilai minimum yang ditunjukkan adalah sebesar $-0,028$, nilai maksimum sebesar 0,009 , mean sebesar $-0,005$, dengan standar deviasi sebesar 0,010 . Nilai mean ratarata AR terindikasi mengalami penurunan dari sebelum ke sesudah peristiwa, dimana nilainya menjadi $-0,005$ setelah peristiwa. Sebaran data pada sebelum peristiwa sedikit lebih besar jika dibandingkan dengan sesudah peristiwa, dilihat dari nilai standar deviasinya.

Rata-rata SRV sebelum peristiwa penetapan presiden dan wakil presiden terpilih 2019-2024 menunjukkan angka minimum sebesar 0,146 dan maksimum sebesar 2,185, dengan mean sebesar 0,867 dan standar deviasi sebesar 0,617. Sementara untuk rata-rata SRV sesudah peristiwa, nilai minimum yang ditunjukkan adalah sebesar 0,068, nilai maksimum sebesar 2,954, mean sebesar 0,995 , dengan standar deviasi sebesar 0,759. Nilai mean rata-rata SRV terindikasi mengalami kenaikan dari sebelum ke sesudah peristiwa. Sebaran data sesudah peristiwa lebih besar jika dibandingkan dengan sebaran data sebelum peristiwa, dilihat dari nilai standar deviasinya.

Statistik deskriptif variabel TVA dijelaskan dalam rata-rata, nilai minimum, dan maksimum. Rata-rata sebelum peristiwa penetapan presiden dan wakil 
presiden terpilih 2019-2024 menunjukkan angka TVA minimum sebesar 0,000 dan maksimum sebesar 0,099, dengan mean sebesar 0,005 dan standar deviasi sebesar 0,022 . Sementara untuk rata-rata TVA sesudah peristiwa, nilai minimumnya adalah sebesar 0,000 , nilai maksimum sebesar 0,019 , mean sebesar 0,001, dengan standar deviasi sebesar 0,004. Berdasarkan perbandingan, dapat dilihat bahwa nilai mean rata-rata TVA terindikasi mengalami penurunan dari sebelum ke sesudah peristiwa. Sebaran data sebelum peristiwa lebih besar jika dibandingkan dengan sebaran data sesudah peristiwa, dilihat dari nilai standar deviasinya.

Tabel 2. Statistik Deskriptif Variabel Penelitian pada Peristiwa Pengumuman Kabinet Indonesia Maju

\begin{tabular}{|c|c|c|c|c|c|}
\hline Variabel & Periode & Minimum & Maximum & Mean & Std Deviation \\
\hline \multirow{2}{*}{$\mathrm{AR}$} & Sebelum & - 0,019 & 0,066 & 0,002 & 0,017 \\
\hline & Sesudah & - 0,039 & 0,023 & - 0,005 & 0,013 \\
\hline \multirow[t]{2}{*}{ SRV } & Sebelum & 0,045 & 1,893 & 0,978 & 0,563 \\
\hline & Sesudah & 0,181 & 2,038 & 1,018 & 0,580 \\
\hline \multirow{2}{*}{ TVA } & Sebelum & 0,000 & 0,111 & 0,006 & 0,022 \\
\hline & Sesudah & 0,000 & 0,177 & 0,011 & 0,035 \\
\hline
\end{tabular}

Sumber: Data Penelitian, 2021

Analisis statistik deskriptif untuk rata-rata AR pada peristiwa pengumuman Kabinet Indonesia Maju sebelum peristiwa pengumuman Kabinet Indonesia Maju menunjukkan angka minimum sebesar -0,018 dan maksimum sebesar 0,065, dengan mean sebesar 0,002 dan standar deviasi sebesar 0,017. Sementara untuk rata-rata AR sesudah peristiwa, nilai minimum yang ditunjukkan adalah sebesar $-0,039$, nilai maksimum sebesar 0,023, mean sebesar --0,005, dengan standar deviasi sebesar 0,563. Berdasarkan sattistik deskriptif, nilai mean rata-rata AR terlihat mengalami kenaikan dari sebelum ke sesudah peristiwa. Sebaran data pada sebelum peristiwa sedikit lebih besar jika dibandingkan dengan sesudah peristiwa, dilihat dari nilai standar deviasinya.

Rata-rata SRV sebelum peristiwa pengumuman Kabinet Indonesia Maju menunjukkan angka minimum sebesar 0,045 dan maksimum sebesar 1,893, dengan mean sebesar 0,978 dan standar deviasi sebesar 0,563226. Sementara untuk rata-rata SRV sesudah peristiwa, nilai minimum yang ditunjukkan adalah sebesar 0,181 , nilai maksimum sebesar 2,038, mean sebesar 1,018, dengan standar deviasi sebesar 0,579. Nilai mean rata-rata SRV terindikasi mengalami kenaikan dari sebelum ke sesudah peristiwa. Sebaran data sebelum peristiwa terlihat sedikit lebih kecil jika dibandingkan dengan sebaran data sesudah peristiwa, dilihat dari nilai standar deviasinya.

Rata-rata TVA sebelum peristiwa pengumuman Kabinet Indonesia Maju menunjukkan angka minimum sebesar 0,00 dan maksimum sebesar 0,110678, dengan mean sebesar 0,006 dan standar deviasi sebesar 0,022. Sementara untuk rata-rata TVA sesudah peristiwa, nilai minimumnya adalah sebesar 0,000 , nilai maksimum sebesar 0,177, mean sebesar 0,011, dengan standar deviasi sebesar 0,034. Dari perbandingan, dapat dilihat bahwa nilai mean rata-rata TVA terindikasi mengalami penurunan dari sebelum ke sesudah peristiwa. Sebaran data sesudah peristiwa lebih besar jika dibandingkan dengan sebaran data sebelum peristiwa, dilihat dari nilai standar deviasinya. 
Tabel 3. Hasil Pengujian Normalitas Variabel Penelitian

\begin{tabular}{cccc}
\hline Variabel & Periode & Peristiwa Politik & One Sample Kolmogorov-Smirnov \\
\hline \multirow{2}{*}{ AR } & Sebelum & Pemilihan Umum 2019 & 0,010 \\
& Sesudah & & 0,037 \\
\multirow{2}{*}{ AR } & Sebelum & Pengumuman Kabinet & 0,040 \\
& Sesudah & Indonesia Maju & 0,020 \\
\multirow{2}{*}{ SRV } & Sebelum & Pemilihan Umum 2019 & 0,061 \\
& Sesudah & & 0,200 \\
\multirow{2}{*}{ SRV } & Sebelum & Pengumuman Kabinet & 0,010 \\
& Sesudah & Indonesia Maju & 0,200 \\
\multirow{2}{*}{ TVA } & Sebelum & Pemilihan Umum 2019 & 0,000 \\
& Sesudah & & 0,000 \\
\multirow{2}{*}{ TVA } & Sebelum & Pengumuman Kabinet & 0,000 \\
& Sesudah & Indonesia Maju & 0,000 \\
\hline
\end{tabular}

Sumber: Data Penelitian, 2021

Tabel 3, menunjukkan hasil uji normalitas terhadap variabel penelitian pada peristiwa penetapan presiden dan wakil presiden terpilih 2019-2024 dan pengumuman Kabinet Indonesia Maju dari 20 sampel perusahaan koalisi pemenang pemilu. Hasil menunjukkan bahwa Pengujian variable abnormal return dan trading volume activity pada peristiwa penetapan pemenang pemilu dan pengumuman Kabinet Indonesia Maju menggunakan pengujian non parametrik Wilcoxon Signed Rank Test sedangkan hanya pengujian variable security return variability pada peristiwa penetapan pemenang pemilu yang menggunakan Paired Sample t test.

Tabel 4. Hasil Pengujian Hipotesis

\begin{tabular}{|c|c|c|c|}
\hline Variabel & Peristiwa Politik & $\begin{array}{l}\text { Wilcoxon Signed } \\
\text { Rank Test }\end{array}$ & $\begin{array}{c}\text { Paired Sample t } \\
\text { test }\end{array}$ \\
\hline AR & Pemilihan Umum 2019 & 0,019 & - \\
\hline AR & $\begin{array}{l}\text { Pengumuman Kabinet } \\
\text { Indonesia Maju }\end{array}$ & 0,192 & - \\
\hline SRV & Pemilihan Umum 2019 & - & 0,665 \\
\hline SRV & $\begin{array}{l}\text { Pengumuman Kabinet } \\
\text { Indonesia Maju }\end{array}$ & 0,861 & - \\
\hline TVA & Pemilihan Umum 2019 & 0,601 & - \\
\hline TVA & $\begin{array}{l}\text { Pengumuman Kabinet } \\
\text { Indonesia Maju }\end{array}$ & 0,000 & - \\
\hline
\end{tabular}

Sumber: Data Penelitian, 2021

Berdasarkan Tabel 4, Hasil pengujian hipotesis, didapatkan hasil berupa perbedaan yang signifikan rata-rata Abnormal Return sebelum dan sesudah penetapan presiden dan wakil presiden terpilih 2019-2024. Hal ini berarti bahwa pelaku pasar bereaksi secara signifikan terhadap peristiwa ini. Peristiwa ini juga dapat dikatakan memiliki kandungan informasi yang bermakna bagi pasar. Selain itu, mengingat pemenangnya adalah incumbent yang diharapkan akan melanjutkan program infrastruktur dan keberlanjutan pertumbuhan ekonomi dan investasi, diharapkan pelaku investor akan merespon peristiwa ini sebagai good news, namun perbedaan yang signifikan ini nyatanya menunjukkan nilai rata-rata 
AR yang mengalami penurunan ke angka negatif pada periode setelah peristiwa. Hal ini kemungkinan terjadi karena banyak investor yang melakukan aksi profit taking saham-saham koalisi Jokowi-Ma'ruf di seputaran periode setelah peristiwa karena menganggap bahwa menangnya Jokowi-Ma'ruf tidak akan secara langsung memberi pengaruh besar terhadap harga-harga saham koalisi ini. Penelitian oleh Chaney et al. (2011), serta penelitian oleh Primastono (2006) menemukan bahwa perusahaan-perusahaan yang memiliki koneksi politik memiliki kualitas laporan keuangan yang lebih rendah dibandingkan dengan perusahaan yang tidak terkoneksi politik. Kualitas laporan keuangan berhubungan dengan pengungkapan informasi mengenai perusahaan, sehingga semakin baik kualitas laporan keuangan maka semakin tepat informasi mewakili realitas ekonomi dan kondisi perusahaan tersebut, sehingga akan meningkatkan keputusan investasi di perusahaan tersebut (Bamidele et al., 2018).

Berdasarkan hasil pengujian hipotesis, rata-rata Security Return Variability sebelum dan sesudah kedua peristiwa; baik penetapan presiden dan wakil presiden terpilih 2019-2024 dan pengumuman Kabinet Indonesia Maju tidak menunjukkan adanya perbedaan yang signifikan sebelum dan sesudah peristiwa. Berdasarkan hasil ini, dapat dikatakan bahwa tidak terdapat kandungan informasi pada kedua peristiwa ini, yang dapat membuat para pelaku pasar bereaksi. Alasan yang memungkinkan adalah karena bisa saja telah terjadi kebocoran informasi sebelum event date, baik tentang presiden dan wakil presiden yang secara resmi terpilih, ataupun menteri-menteri yang akan menduduki posisi kabinet terbaru, dimana para investor sudah lebih dulu menyerap informasi ini dan melakukan tindakan, sehingga setelah peristiwa tidak ada lagi 'kejutan' bagi investor yang dapat menyebabkan adanya perbedaan yang signifikan atas variabilitas tingkat keuntungan setelah peristiwa. Hasil penelitian ini mendukung hasil penelitian sebelumnya dari Zaqi (2006), Aditha \& Adiputra (2020), serta Ratnaningsih (2020), namun tidak sejalan dengan penelitian dari Musyarrofah (2016).

Hasil pengujian beda rata-rata trading volume activity pada periode sebelum dan sesudah peristiwa penetapan presiden dan wakil presiden terpilih 2019-2024 tidak menunjukkan adanya perbedaan yang signifikan. Tidak adanya reaksi pasar atas peristiwa ini dapat menandakan bahwa tidak terdapat kandungan informasi yang signifikan memengaruhi keputusan para investor di pasar modal untuk melakukan transaksi perdagangan yang menyebabkan pergerakan volume aktivitas perdagangan yang signifikan. Para pelaku pasar kemungkinan tidak melakukan keputusan jual atau beli saham dengan jumlah yang signifikan karena masih memiliki keraguan akan konsep dan program presiden dan wakil presiden yang baru sehingga mereka lebih baik menunggu sampai masa kepemimpinan yang baru sudah berjalan. Hasil penelitian ini mendukung beberapa penelitian sebelumny, yaitu (Nida et al. 2020), dan (Ratnaningsih, 2020).

Hasil pengujian hipotesis uji beda rata-rata Trading Volume Activity sebelum dan sesudah pengumuman Kabinet Indonesia Maju menunjukkan hasil yang signifikan. Terdapat perbedaan yang signifikan antara rata-rata Trading Volume Activity sebelum dan sesudah peristiwa pengumuman Kabinet Indonesia Maju yang juga berarti bahwa terdapat reaksi yang signifikan dari pelaku pasar terhadap peristiwa ini. Adanya reaksi mencerminkan bahwa terdapat kandungan informasi dalam peristiwa ini yang mampu membuat investor mengambil 
keputusan melakukan pembelian saham-saham perusahaan koalisi JokowiMa'ruf, sehingga volume aktivitas perdagangan saham-saham perusahaan mengalami perubahan signifikan yang cenderung naik. Hal ini dapat berarti bahwa para investor menaruh perhatian terhadap perusahaan-perusahaan koalisi Jokowi-Ma'ruf, karena beberapa dari petinggi perusahaan tersebut merupakan salah satu pemilik atau pemegang saham perusahaan-perusahaan koalisi ini, sehingga ada kemungkinan nantinya perusahaan-perusahaan ini mendapatkan akses yang lebih mudah yang berkaitan dengan regulasi pemerintahan, misalnya tarif pajak yang lebih rendah, atau kekuatan pasar yang lebih tinggi (Faccio, 2011). Para investor juga merasa yakin terhadap menteri-menteri di Kabinet Indonesia Maju, melihat beberapa tokoh baik politik maupun non-politik yang memiliki track record yang baik, seperti Sri Mulyani dan Erick Thohir yang menjabat sebagai menteri. Hal ini dapat dianggap sebagai sentimen positif yang akan meningkatkan pertumbuhan ekonomi Indonesia di masa yang akan datang. Selain itu, momen ini juga dimanfaatkan oleh trader untuk melakukan transaksi perdagangan di sekitar periode dengan membeli saham-saham ini untuk meningkatkan keuntungan. Hasil penelitian ini mendukung hasil penelitian sebelumnya dari Arviani \& Khoirunnisa (2020), namun bertolak belakang dengan penelitian dari (Aditha \& Adiputra 2020) dan (Primastono 2006).

\section{SIMPULAN}

Hasil analisis dan pembahasan yang telah dipaparkan sebelumnya dapat ditarik kesimpulan bahwa terdapat perbedaan rata-rata abnormal return yang signifikan antar kedua periode pengamatan tersebut. Perbedaan yang signifikan juga mengimplikasikan bahwa terdapat kandungan informasi dalam peristiwa ini yang mampu diserap oleh investor. Hasil pengujian hipotesis uji beda rata-rata security return variability lima hari sebelum dan lima hari sesudah peristiwa penetapan Presiden dan Wail Presiden Terpilih 2019-2024 serta pengumuman Kabinet Indonesia Maju secara serempak menunjukkan bahwa tidak adanya perbedaan yang signifikan antara rata-rata security return variability sebelum dan sesudah peristiwa. Security return variability tidak memiliki kandungan informasi yang signifikan yang mampu memicu reaksi pasar. Hasil pengujian hipotesis uji beda rata-rata pada rata-rata trading volume activity lima hari sebelum dan lima hari sesudah peristiwa penetapan presiden dan wakil presiden terpilih 2019-2024 menunjukkan tidak adanya perbedaan yang signifikan antara rata-rata trading volume activity sebelum dan sesudah peristiwa, sehingga dapat disimpulkan bahwa tidak adanya kandungan informasi yang signifikan yang dapat memicu reaksi pasar terhadap peristiwa ini. Hasil uji beda rata-rata trading volume activity lima hari sebelum dan sesudah peristiwa pengumuman Kabinet Indonesia Maju menunjukkan bahwa terdapat perbedaan yang signifikan antara rata-rata trading volume activity sebelum dan sesudah peristiwa ini. Kesimpulan yang dapat ditarik adalah terdapat kandungan informasi yang menyebabkan reaksi pasar yang signifikan terhadap peristiwa ini.

Penelitian ini hanya menggunakan total sampel perusahaan sejumlah 25 perusahaan afiliasi dengan pemenang pemilu, yaitu perusahaan-perusahaan yang tergabung dalam tim pemenangan Jokowi-Ma'ruf atau mendeklarasikan dukungan kepada Jokowi-Ma'ruf, sehingga kemungkinan belum dapat 
menjelaskan kondisi yang sebenranya terjadi di pasar modal. Selain itu, penelitian ini hanya menggunakan metode market adjusted model sebagai model perhitungan return ekspektasian. Untuk pengembangan dan penyempuranaan penelitian selanjutnya, disarankan agar mempertimbangkan metode perhitungan lain seperti market model, mean-adjusted model, atau CAPM.

\section{REFERENSI}

Aditha, K. K., \& Adiputra, I. M. P. (2020). Analisis Perbedaan Abnormal Return , Trading Volume Activity, Dan Security Return Variability Pada Perusahaan Lq 45 Pra Dan Pasca Pengumuman Kabinet Indonesia Maju Periode 20192024. JIMAT (Jurnal Ilmiah Mahasiswa Akuntansi) Universitas Pendidikan Ganesha, 11(2).

Arviani, H. A., \& Khoirunnisa, R. M. (2020). Reaksi Saham Indeks Jii Terhadap Pengumuman Reshuffle Kabinet Kerja Tahun 2015 Di Bursa Efek Indonesia. Jurnal Fokus Manajemen Bisnis, 7(1), 36. https://doi.org/10.12928/fokus.v7i1.1706

Bamidele, Ibrahim, \& Omole. (2018). Financial Reporting Quality and Its Effect on Investment Decisions By Nigerian Deposit Money Banks. European Journal of Accounting, Auditing and Finance Research, 6(4), 23-34. Retrieved from www.eajournals.org

Bechtel, M. M. (2009). The political sources of systematic investment risk: Lessons from a consensus democracy. Journal of Politics, 71(2), 661-677. https://doi.org/10.1017/S0022381609090525

Chaney, P. K., Faccio, M., \& Parsley, D. (2011). The quality of accounting information in politically connected firms. Journal of Accounting and Economics, 51(1-2), 58-76. https://doi.org/10.1016/j.jacceco.2010.07.003

Chavali, K., Alam, M., \& Rosario, S. (2020). Stock market response to elections: An event study method. Journal of Asian Finance, Economics and Business, 7(5), 918. https:// doi.org/10.13106/JAFEB.2020.VOL7.NO5.009

Faccio, M. (2011). Differences between Politically Connected and Non-Connected Firms: A Cross Country Analysis. SSRN Electronic Journal. https://doi.org/10.2139/ssrn.918244

Fama, E. F., \& French, K. R. (2005). Financing decisions: who issues stock? Journal of Financial Economics, 76, 549-582. https://doi.org/10.1016/j.jfineco.2004.10.003

Fidiana, F. (2020). Market Reaction on the Announcement of Elected President. Journal of Accounting and Strategic Finance, 3(1), 71-87. https://doi.org/10.33005/jasf.v3i1.77

Flore, C., Kolaric, S., \& Schiereck, D. (2017). Settlement agreement types of federal corporate prosecution in the U.S. and their impact on shareholder wealth. Journal of Business Research, 76, 145-158. https://doi.org/https://doi.org/10.1016/j.jbusres.2017.03.015

Ghofar, A., \& Aunilah, R. A. (2016). The influence of accrual anomaly and winnerloser anomaly on abnormal return: The Indonesian evidence. DLSU Business and Economics Review, 26(1), 101-121.

Gupta, A., Misra, L., \& Shi, Y. (2017). Product-market competitiveness and investor reaction to corporate governance failures. International Review of Economics $\mathcal{E}$ 
Finance,

48,

134-147. https://doi.org/https://doi.org/10.1016/j.iref.2016.11.014

Irshad, H. (2017). Relationship Among Political Instability, Stock Market Returns and Stock Market Volatility. Studies in Business and Economics, 12(2), 70-99. https://doi.org/10.1515/sbe-2017-0023

Jiun, R. C. C. (2018). The effect of political elections on stock market volatility in Malaysia. International Journal of Engineering and Technology(UAE), 7(3), 114119. https:// doi.org/10.14419/ijet.v7i3.21.17105

KARPOFF, J. M. (1986). A Theory of Trading Volume. The Journal of Finance, 41(5), 1069-1087. https://doi.org/10.1111/j.1540-6261.1986.tb02531.x

McNichols, M., \& Manegold, J. G. (1983). The effect of the information environment on the relationship between financial disclosure and security price variability. Journal of Accounting and Economics, 5(C), 49-74. https:// doi.org/10.1016/0165-4101(83)90005-8

Mei, J., \& Guo, L. (2004). Political uncertainty, financial crisis and market volatility. European Financial Management, 10(4), 639-657. https:// doi.org/10.1111/j.1354-7798.2004.00269.x

Mnasri, A., \& Essaddam, N. (2021). Impact of U.S. presidential elections on stock markets' volatility: Does incumbent president's party matter? Finance Research Letters, 39(May), 101622. https://doi.org/10.1016/j.frl.2020.101622

Musyarrofah, A. (2016). Reaksi Pasar Modal Indonesia Sebelum dan Sesudah Reshuffle Kabinet 12 Agustus 2015 (Event Study pada Saham Anggota LQ 45 Tahun 2015). Jurnal Akuntansi Unesa, 4(3), 1-18. Retrieved from https://jurnalmahasiswa.unesa.ac.id/index.php/jurnalakuntansi/article/view/15084

Nida, D. R. P. P., Yoga, I. G. A. P., \& Adityawarman, I. M. G. (2020). Analisis Reaksi Pasar Modal Terhadap Peristiwa Pemilu Serentak Tahun 2019. WICAKSANA: Jurnal Lingkungan Dan Pembangunan, 4(1), 64-73. https:// doi.org/10.22225/wicaksana.4.1.1813.64-73

Nurlita, V., \& Naomi, P. (2019). Do Political Events Affect Stock Return Volatility On Indonesian Stock Exchange. Journal of Economics, Business \& Accountancy Ventura, 22(1), 29-38. https:// doi.org/10.14414/jebav.v22i1.1215

Obradovic, S., \& Tomic, N. (2017). The effect of presidential election in the USA on stock return flow - a study of a political event. Economic Research-Ekonomska Istraživanja.

Pastor, L., \& Veronesi, P. (2012). Uncertainty About Government Policy and Stock Prices. SSRN Electronic Journal. https://doi.org/10.2139/ssrn.1625845

Primastono, I. (2006). Analisis Perbandingan Peristiwa Pengumuman Kabinet Gotong Royong Dan Kabinet Indonesia Bersatu Terhadap Reaksi Harga Saham Dan Likuiditas Saham. Retrieved from http://eprints.undip.ac.id/17797/

Ratnaningsih, A. (2020). Abnormal Return, Trading Volume Activity, Dan Security Return Variability Sebelum Dan Sesudah Pengumuman Hasil Pemilu Presiden Indonesia Tanggal 21 Mei 2019 (Studi Pada Perusahaan Yang Tercatat Sebagai Anggota Indeks LQ 45). 1-23.

Sajid Nazir, M., Younus, H., Kaleem, A., \& Anwar, Z. (2014). Impact of political events on stock market returns: empirical evidence from Pakistan. Journal of Economic and Administrative Sciences, 30(1), 60-78. 
https:// doi.org/10.1108/jeas-03-2013-0011

Setiawan, D., \& Maret, U. S. (2008). An Analysis Of Market Reaction To CEO Turnover Announcement : 7(2), 119-128.

Shen, C. H., \& Lin, C. Y. (2015). Betting on presidential elections: Should we buy stocks connected with the winning party? Quarterly Review of Economics and Finance, 56, 98-109. https:// doi.org/10.1016/j.qref.2014.09.007

Suleman, M. T. (2012). Stock Market Reaction to Good and Bad Political News. Asian Journal of Finance $\mathcal{E}$ Accounting, 4(1). https:// doi.org/10.5296/ajfa.v4i1.1705

Wisniewski, T. P. (2016). Is there a link between politics and stock returns? A literature survey. International Review of Financial Analysis, 47, 15-23. https://doi.org/10.1016/j.irfa.2016.06.015

Yeh, Y.-H., Shu, P.-G., \& Chiu, S.-B. (2013). Political connections, corporate governance and preferential bank loans. Pacific-Basin Finance Journal, 21(1), 1079-1101. https://doi.org/https://doi.org/10.1016/j.pacfin.2012.08.003

Zaqi, M. (2006). Reaksi Pasar Modal Indonesia Terhadap Peristiwa - Peristiwa Ekonomi Dan Peristiwa - Peristiwa Sosial-Politik Dalam Negeri (Studi Pada Saham LQ45 Di BEJ Periode 1999-2003). Tesis, Semarang: Universitas Diponegoro. 